\title{
To concentrate or ventilate? Carbon acquisition, isotope discrimination and physiological ecology of early land plant life forms
}

\begin{abstract}
Moritz Meyer, Ulli Seibt and Howard Griffiths*
Physiological Ecology Group, Department of Plant Sciences, University of Cambridge, Downing Street, Cambridge CB2 3EA, UK

A comparative study has been made of the photosynthetic physiological ecology and carbon isotope discrimination characteristics for modern-day bryophytes and closely related algal groups. Firstly, the extent of bryophyte distribution and diversification as compared with more advanced land plant groups is considered. Secondly, measurements of instantaneous carbon isotope discrimination $(\Delta)$, photosynthetic $\mathrm{CO}_{2}$ assimilation and electron transport rates were compared during the drying cycles. The extent of surface diffusion limitation (when wetted), internal conductance and water use efficiency (WUE) at optimal tissue water content (TWC) were derived for liverworts and a hornwort from contrasting habitats and with differing degrees of thallus ventilation (as intra-thalline cavities and internal airspaces). We also explore how the operation of a biophysical carbon-concentrating mechanism (CCM) tempers isotope discrimination characteristics in two other hornworts, as well as the green algae Coleochaete orbicularis and Chlamydomonas reinhardtii. The magnitude of $\Delta$ was compared for each life form over a drying curve and used to derive the surface liquid-phase conductance (when wetted) and internal conductance (at optimal TWC). The magnitude of external and internal conductances, and WUE, was higher for ventilated, compared with non-ventilated, liverworts and hornworts, but the values were similar within each group, suggesting that both factors have been optimized for each life form. For the hornworts, leakiness of the CCM was highest for Megaceros vincentianus and C. orbicularis (approx. 30\%) and, at 5\%, lowest in C. reinhardtii grown under ambient $\mathrm{CO}_{2}$ concentrations. Finally, evidence for the operation of a CCM in algae and hornworts is considered in terms of the probable role of the chloroplast pyrenoid, as the origins, structure and function of this enigmatic organelle are explored during the evolution of land plants.
\end{abstract}

Keywords: bryophytes; carbon-concentrating mechanisms; carbon isotopes; mesophyll conductance; pyrenoid

\section{INTRODUCTION}

The bryophytes, represented today by liverworts, hornworts and mosses (Renzaglia et al. 2007), are the group of plants thought to be the closest living representatives of those plants which evolved from the Mesostigma lineage, via the Coleochaetales and Charales (Lewis \& McCourt 2004; Turmel et al. 2007), to become land plants in the Late Silurian (Edwards et al. 1998; Graham \& Gray 2001). Despite their diversity being only surpassed by the flowering plants (Renzaglia et al. 2007), and having contributed significantly to the global carbon storage in peats and mires (Clymo \& Hayward 1982; Campbell et al. 2000; Gunnarsson 2005), bryophyte diversification is normally thought to be limited by life cycle. Thus, the alternation of generations is dominated by a haploid gametophyte with indeterminate growth form. The requirement for liquid water in liverworts and hornworts, both to promote reproduction and to maintain tissue turgor, suggests these to be shade-demanding life forms (Green \& Lange 1994; Marschall \& Proctor

* Author for correspondence (hg230@cam.ac.uk).

One contribution of 15 to a Discussion Meeting Issue 'Photosynthetic and atmospheric evolution'.
2004), which also could have constrained diversification (except for mosses, Stoneburner et al. 1991). Many mosses have become highly tolerant of desiccation, by recourse to a resurrection strategy (Proctor \& Pence 2002; Proctor et al. 2007; Wood 2007). Overall, none of the three groups have developed a significant degree of cuticularization, stomata and water transport tissues, and then only in specialized tissues in certain groups (e.g. stomata in sporophytes of mosses and hornworts: Edwards et al. 1998; Renzaglia et al. 2004, 2007; Shaw \& Renzaglia 2004).

While there is reasonable evidence for thalloid life forms in the early fossil record (Wellman et al. 2003; Graham et al. 2004; Taylor \& Haas 2005), and they are certainly rooted as forerunners of the land plant revolution from their molecular phylogenies, we have little in the way of a fossil record to reconstruct their subsequent diversification. Recently, however, it has been suggested that some leafy liverworts have indeed shown significant speciation since the angiosperms arose (Ahonen et al. 2003; Heinrichs et al. 2007; Wilson et al. 2007), presumably diversifying in the lee of forest canopies, just as it had been posited for ferns (Schneider et al. 2004). It would now be interesting to compare speciation in liverworts with that in ferns 
across tropical and temperate biomes, to assess whether the potential advantages of the haploid life cycle (higher degree of speciation) was met by a trade-off with increased susceptibility to lethal mutations, for families of ferns and bryophytes, which has ultimately constrained diversity over palaeohistorical time scales.

The specific focus of this paper, however, is the physiological implications of the thallus complexity found in liverwort and hornwort gametophytes. Here, the progression towards the aspects of modern-day leaf architecture can be visualized, from groups with simple, undifferentiated thalli (in the genus Pellia and most hornworts) to increased 'ventilation'. This can be seen by the development of pores and cavities beneath the outer epidermal layer, lined with chlorenchyma, as well as increased internal airspaces within tissues (as exemplified by Conocephalum, Lunularia and Marchantia-for a detailed morphological study in Marchantia, see Apostolakos et al. (1982)). In addition, the relationship between the origins and activity of a biophysical carbon-concentrating mechanism (CCM) in some uniplastidic hornworts is a continuing interest (Griffiths et al. 2004).

Carbon isotope discrimination reflects CCM activity whether in organic material or in real time, from instantaneous isotope discrimination during photosynthetic gas exchange (Smith \& Griffiths 1996a,b, 2000). A comparison of gas exchange characteristics for a morphological progression in thallus structure showed that the hornwort Phaeoceros had carbon assimilation rates equivalent to the ventilated Marchantia under current ambient $\mathrm{CO}_{2}$ concentrations, in contrast to the diffusion-limited Pellia (Griffiths et al. 2004). Thus, we suggested that the CCM, if derived from the Coleochaete lineage, was perhaps unnecessary for land plants colonizing the aerial environment, when increased thallus ventilation could lead to a concomitant increase in mesophyll (internal) conductance to $\mathrm{CO}_{2}$. The increasing competition for light was a selection pressure that led to progressive improvements in stomatal conductance (density) and xylem function (Edwards et al. 1998; Raven 2003), together with a switch to a sporophytedominated life form, which eventually led to the rise of all modern-day complex land plants.

The work reported in this paper develops a systematic analysis of photosynthetic carbon assimilation, carbon isotope discrimination and electron transport characteristics for contrasting liverwort and hornwort life forms, from hydric and mesic habitats. By comparing the rates of carbon gain and water loss during the drying curves for each life form, we have determined the optimal tissue water content (TWC) for photosynthesis and compared the efficiencies of light use and carbon gain. The measurement of online, instantaneous carbon isotope discrimination has been used to derive the surface, liquid-phase limitation when wetted, and maximal internal conductance for C3 liverworts, or the extent of leakiness for the CCM in hornworts. In addition, we present data on the photosynthetic physiology of representatives of the charophytes and the chlorophytes (Coleochaete orbicularis and Chlamydomonas reinhardtii), which both concentrate rubisco in a pyrenoid, for comparison with the most closely related land plant lineages.

\section{MATERIAL AND METHODS}

\section{(a) Plant material collection}

The bryophyte material used in the study was collected during 2006 and 2007. Liverworts were identified to the species level using the keys of Schumaker \& Váňa (2005). The collecting sites are given in table 1 . Algal strains were acquired from algal collections.

\section{(b) Growth conditions}

All liverwort and hornwort materials used for the gas exchange, isotopic discrimination and fluorescence measurements were grown at the University of Cambridge Botanic Garden, in a glasshouse equipped with an automatic misting unit. Marchantia polymorpha and Pellia epiphylla were kept outside the direct spray zone.

Cultures were protected from direct sunlight with a plastic mesh, allowing a maximum of $60 \mu \mathrm{mol}$ photons $\mathrm{m}^{-2} \mathrm{~s}^{-1}$ under full irradiation. Photoperiod and temperature were not controlled (no artificial light or heat source). Temperature fluctuated from maximum $28^{\circ} \mathrm{C}$ in July 2006 to minimum $7^{\circ} \mathrm{C}$ in January 2007 . Plants were grown individually in small plastic trays $(6 \times 6 \mathrm{~cm})$ on ordinary compost. Under these conditions, it took an average of one month for Marchantia gemmae to grow to a full sized thallus of $10 \mathrm{~cm}^{2}$, and three months at least to regenerate, from a thallus fragment, a similar sized Phaeoceros rosette.

Chlamydomonas was grown photoautotrophically in $500 \mathrm{ml}$ conical glass vials half filled with minimal medium (Surzycki 1971 ) at $25^{\circ} \mathrm{C}$ under $60 \mu \mathrm{mol}$ photons $\mathrm{m}^{-2} \mathrm{~s}^{-1}$ with moderate shaking (100 r.p.m.) in an orbital incubator shaker (Gallenkamp, Loughborough, UK). Coleochaete was grown under similar conditions, using Bold modified basal freshwater nutrient solution (Sigma, St Louis, USA) instead. Chlamydomonas cultures were refreshed with a $200 \mu \mathrm{l}$ inoculum when reaching mid-logarithmic phase $\left(2 \times 10^{6}\right.$ cells $\mathrm{ml}^{-1}$ ); considerably slower growing Coleochaete cultures were refreshed every two months on average. Algal cells were collected by centrifugation ( $4000 \mathrm{~g}$ for $5 \mathrm{~min}$ ) and the pellet was evenly spread on a filter paper to mimic the chlorophyllous layer of a thallus prior to measurements.

\section{(c) General protocol for laboratory experiments}

Experiments were run to simultaneously investigate the response of isotopic discrimination, net carbon assimilation and chlorophyll fluorescence to changes in degree of hydration, over a range of water contents.

Replicate $(5 \times)$ bryophyte and algal samples were collected from growth chambers immediately before measurements. Rhizoids were removed when necessary. The plant material $\left(10 \mathrm{~cm}^{2}\right)$ was first saturated with distilled water by complete immersion. Excess external capillary water was dry blotted, giving a measure of the fully turgid weight (TW). Tissues were subsequently rewetted to restore the superficial liquid layer and reweighed to determine fresh weight (FW), prior to being placed in a gas exchange cuvette. Each complete drying cycle consisted of successive net assimilation rate measurement and gas sample collection for isotopic composition, interrupted at regular intervals to measure the new FW value, as well as fluorescence. Depending on the species, a complete drying cycle took between 4 and 8 hours. Data were finally expressed in percentage of water content at a given time as related to the water content at full turgor, according to Slatyer (1967): 
Table 1. List of species used in the study, life form, carbon metabolism, and collection site.

\begin{tabular}{|c|c|c|c|}
\hline species & $\begin{array}{l}\text { gametophyte morphology }{ }^{\mathrm{a}} \text { and expected } \\
\text { C metabolism }\end{array}$ & collection site & collector \\
\hline \multicolumn{4}{|l|}{$\begin{array}{l}\text { Marchantiophyta } \\
\text { (liverworts) }\end{array}$} \\
\hline Pellia endiviifolia & simple thallus, no pores, $\mathrm{C} 3$ & $\begin{array}{l}\text { Sart Tilman, Liège, Belgium (banks of } \\
\text { Blanc Gravier brook) }\end{array}$ & M. Meyer \\
\hline Pellia epiphylla & simple thallus, no pores, $\mathrm{C} 3$ & $\begin{array}{l}\text { River Frome, Stroud, Glos, UK } \\
\quad \text { (shaded stones by fast flowing water) }\end{array}$ & H. Griffiths \\
\hline $\begin{array}{l}\text { Conocephalum } \\
\text { conicum }\end{array}$ & complex thallus, pores, $\mathrm{C} 3$ & $\begin{array}{l}\text { Botanic Garden, Cambridge, UK } \\
\text { (weeds in glasshouses) }\end{array}$ & M. Meyer \\
\hline $\begin{array}{l}\text { Lunularia } \\
\text { cruciata }\end{array}$ & complex thallus, pores, C3 & $\begin{array}{l}\text { Botanic Garden, Cambridge, UK } \\
\quad \text { (weeds outside glasshouses) }\end{array}$ & M. Meyer \\
\hline $\begin{array}{l}\text { Marchantia } \\
\text { polymorpha }\end{array}$ & complex thallus, pores, $\mathrm{C} 3$ & $\begin{array}{l}\text { Clare College Old Court, Cambridge, } \\
\text { UK (between cobbled stones in shade) }\end{array}$ & M. Meyer \\
\hline \multicolumn{4}{|c|}{$\begin{array}{l}\text { Anthocerotophyta } \\
\text { (hornworts) }\end{array}$} \\
\hline $\begin{array}{l}\text { Megaceros cf. } \\
\quad \text { fuegiensis }\end{array}$ & $\begin{array}{l}\text { simple thallus, no pores, no pyrenoid, } \\
\text { C3-like }\end{array}$ & Chile & B. Goffinet \\
\hline $\begin{array}{l}\text { Megaceros cf. } \\
\quad \text { vincentianus }\end{array}$ & $\begin{array}{l}\text { simple thallus, no pores, pyrenoid mainly } \\
\text { in the younger uniplastidic cells of the } \\
\text { growing thallus margins but not in the } \\
\text { multiplastidic cells elsewhere, CCM? }\end{array}$ & $\begin{array}{l}\text { Alto de Piedra, Santa Fé, Panamá (on } \\
\text { rock, growing with Monoclea } \\
\text { gottscheii, shaded trail along the } \\
\text { border of a patch of forest) }\end{array}$ & $\begin{array}{l}\text { J. C. Villarreal } \\
\text { and E. O. } \\
\text { Rodriguez }\end{array}$ \\
\hline $\begin{array}{l}\text { Phaeoceros } \\
\quad \text { carolinianus }\end{array}$ & $\begin{array}{l}\text { simple thallus, no pores, uniplastidic cells } \\
\text { with a pyrenoid, CCM }\end{array}$ & $\begin{array}{l}\text { Australian National Botanic Garden, } \\
\text { Canberra, Australia (glasshouse grown } \\
\text { on soil) }\end{array}$ & D. C. Cargill \\
\hline \multicolumn{4}{|l|}{ Charophyta } \\
\hline $\begin{array}{l}\text { Coleochaete } \\
\text { orbicularis }\end{array}$ & $\begin{array}{l}\text { usually unistratose thallus, pyrenoid, } \\
\text { CCM? }\end{array}$ & UTEX Collection of Algae LB 2651 & L. Graham \\
\hline \multicolumn{4}{|l|}{ Chlorophyta } \\
\hline $\begin{array}{l}\text { Chlamydomonas } \\
\text { reinhardtii }\end{array}$ & single cell, pyrenoid, CCM & the chlamydomonas center & \\
\hline
\end{tabular}

relative water content $(\mathrm{RWC})=(\mathrm{FW}-\mathrm{DW}) /(\mathrm{TW}-\mathrm{DW})$, where DW is the dry weight. Because RWC based on saturated water content in bryophytes is not physiologically comparable with values found in vascular plants (Proctor et al. 1998), in the text we refer to values as TWC. TWC for blotted thalli was thus arbitrarily set to $100 \%$, which was generally close to the optimal TWC, at which net assimilation, carbon isotope discrimination and electron transport rate (ETR) were maximal.

\section{(d) Gas exchange system}

An open gas exchange system was designed using a modified LD2/3 Leaf-Disk Oxygen Electrode Chamber (Hansatech Instruments Ltd, King's Lynn, UK) as the cuvette. Uniform illumination was provided through a LH36/2R 36 red LED Array light housing (Hansatech Instruments Ltd, King's Lynn, UK). The photosynthetic photon flux density inside the chamber was monitored using a quantum sensor (model LI-189, Li-Cor, Lincoln, USA). A perforated disc (washer) placed on the floor of the chamber allowed for easy removal of the material in between weighing. The light intensity for each drying cycle was set at saturating intensity, determined beforehand (see $\$ 2 \mathrm{~g}$ ). Temperature control was achieved with a circulating water bath (FC15/FH15, Grant Instruments Cambridge Ltd, Cambridge, UK) through an upper and lower water jacket of the cuvette, and set at $20^{\circ} \mathrm{C}$.
Compressed air from a high-pressure cylinder was supplied at a constant flow rate using a mass flow meter and controller $(5800$ Series, Brooks Instruments BV, Veenendaal, The Netherlands). $\mathrm{CO}_{2}$ concentration of the air exiting the chamber was measured using an infrared gas analyser (ADC 225 MkIII, ADC BioScientific Ltd, Hoddesdon, UK) and recorded on a data logger. The net photosynthetic rate was calculated as the rate of depletion of $\mathrm{CO}_{2}$ per square metre of plant material (based on the $10 \mathrm{~cm}^{2}$ sample of tissue) per second.

After initial placement into the gas chamber, the plant material was given approximately $30 \mathrm{~min}$ to equilibrate to the chamber conditions and reach steady-state gas exchange. Optimal water use efficiency (WUE) was determined as $\left(\mathrm{mol} \mathrm{CO}_{2} \cdot \mathrm{mol} \mathrm{H}_{2} \mathrm{O}^{-1} \cdot 10^{-3}\right)$ from the $\mathrm{FW}$ loss of the measured tissue, over the intervals of maximal $\mathrm{CO}_{2}$ assimilation, converted to water loss on an area basis.

\section{(e) Online carbon isotope discrimination}

$\mathrm{CO}_{2}$ samples were collected downstream of the cuvette, and trapped into a vacuum line, which included the provision for the elimination of water vapour contaminants prior to mass spectrometry. The isotopic composition was measured using a VG Sira mass spectrometer (modified by Pro-Vac Services Ltd, Crewe, UK). 
In an open gas exchange system, discrimination during photosynthesis becomes the difference between the isotopic composition of the air passing over a plant $\left(\delta_{\mathrm{e}}\right.$, 'entering') and the air collected afterwards ( $\delta_{\mathrm{o}}$, 'out'). From the measured concentrations of $\mathrm{CO}_{2}$ entering $\left(C_{\mathrm{e}}\right)$ and leaving $\left(C_{\mathrm{o}}\right)$ a leaf chamber, it is therefore possible to calculate $\Delta$ as (Evans et al. 1986)

$\Delta=\frac{\xi\left(\delta_{\mathrm{e}}-\delta_{\mathrm{o}}\right)}{1000+\delta_{\mathrm{o}}-\xi\left(\delta_{\mathrm{o}}-\delta_{\mathrm{e}}\right)}$,

where

$\xi=\frac{C_{\mathrm{e}}}{C_{\mathrm{e}}-C_{\mathrm{o}}}$.

(f) Calculating conductances and leakage from online carbon isotope discrimination

Carbon isotope discrimination during photosynthesis by C3 plants was derived from the expressions of Farquhar et al. (1989), and developed by Seibt et al. (2008) as

$\Delta=a_{\mathrm{b}} \frac{C_{\mathrm{a}}-C_{\mathrm{s}}}{C_{\mathrm{a}}}+a_{\mathrm{m}} \frac{C_{\mathrm{s}}-C_{\mathrm{c}}}{C_{\mathrm{a}}}+b \frac{C_{\mathrm{c}}}{C_{\mathrm{a}}}-f \frac{\Gamma_{*}}{C_{\mathrm{a}}}$,

where $C_{\mathrm{a}}, C_{\mathrm{s}}$ and $C_{\mathrm{c}}$ are the $\mathrm{CO}_{2}$ mole fractions of ambient air, thallus surface and carboxylation sites, respectively; $a_{\mathrm{b}}$ is the fractionation $\left(2.9 \%\right.$ ) during $\mathrm{CO}_{2}$ diffusion through the leaf boundary layer; $a_{\mathrm{m}}$ is the fractionation during the internal (mesophyll) $\mathrm{CO}_{2}$ transfer $(1.8 \%$ ); $b$ is the fractionation during carboxylation $(27 \% 0) ; f$ is the fractionation during photorespiration (approx. $8 \%$ ); and $\Gamma_{*}$ is the $\mathrm{CO}_{2}$ compensation point in the absence of dark respiration. Equation (2.3) describes the 'optimal' situation, i.e. the thallus is fully hydrated (TWC $\approx 100 \%$ ) but without additional water on its surface. To account for the effect of an external layer of liquid water (TWC $>100 \%$ ), $C_{\mathrm{s}}$ is replaced by $C_{\mathrm{x}}$, the $\mathrm{CO}_{2}$ mole fraction at the surface of the external liquid layer

$\Delta=a_{\mathrm{b}} \frac{C_{\mathrm{a}}-C_{\mathrm{x}}}{C_{\mathrm{a}}}+a_{\mathrm{m}} \frac{C_{\mathrm{x}}-C_{\mathrm{c}}}{C_{\mathrm{a}}}+b \frac{C_{\mathrm{c}}}{C_{\mathrm{a}}}-f \frac{\Gamma_{*}}{C_{\mathrm{a}}}$,

extending the liquid diffusion term to include the external water layer between ambient air and the thallus surface. Based on the measured boundary layer conductance and net $\mathrm{CO}_{2}$ assimilation $(A)$, we calculated $C_{\mathrm{c}}$ from equation (2.3), and using Fick's law, $A=g_{1}\left(C_{\mathrm{s}}-C_{\mathrm{c}}\right)$, determined the total liquid conductance, $g_{1}$. For each experiment, $g_{1}$ can be partitioned into internal and external liquid conductances $\left(1 / g_{1}=1 / g_{\text {int }}+1 / g_{\text {liq }}\right)$. At optimal TWC (approx. $\left.100 \%\right)$, i.e. without external water, $g_{1}$ represents solely the internal (mesophyll) conductance, $g_{\text {int }}$. At TWC $>100 \%$, the external liquid conductance, $g_{\text {liq }}$, was then calculated from $g_{1}$ and $g_{\text {int }}$.

For the derivation of leakiness from the CCM, the approach of Berry (1989) was used,

$\Delta=a_{\mathrm{m}} \frac{F_{1}-F_{3}}{F_{1}}+b \frac{F_{3}}{F_{1}}$,

where $F_{1}$ is the carbon flux into; $F_{3}$ is the flux leaking out of the cells; and $a_{\mathrm{m}}$ combines the discrimination during dissolution (1.1\%o) of $\mathrm{CO}_{2}$ and liquid diffusion (0.7\%o), assuming that $\mathrm{CO}_{2}$ is the substrate of photosynthesis. The ratio of $F_{3} / F_{1}$ represents the 'leakiness' of the pyrenoid-CCM system, $L$, so that equation (2.5) can also be written as

$\Delta=a_{\mathrm{m}}+\left(b-a_{\mathrm{m}}\right) L$.

\section{(g) Fluorescence}

Chlorophyll fluorescence has been widely used as a rapid and non-invasive method to infer plant photosynthetic performance (Maxwell \& Johnson 2000). In vivo chlorophyll $a$ fluorescence was measured at intervals during gas exchange, using a miniaturized pulse amplitude-modulated fluorometer (Mini-PAM, H. Walz, Effeltrich, Germany). The terminology for fluorescence parameters follows that of Maxwell \& Johnson (2000). First, instant light response curves of relative ETR through photosystem II were constructed for each plant material, using the scripting facility of the Mini-PAM, to determine saturating light levels used in the gas exchange system. Ft and $\mathrm{Fm}^{\prime}$ were recorded for the calculation of $\Phi_{\text {PSII }}$ and ETR. $\Phi_{\text {PSII }}$, the quantum yield of PSII, measures the proportion of absorbed energy used in photochemistry, and was calculated as $\Phi_{\mathrm{PSII}}=\left(\mathrm{Fm}^{\prime}-\mathrm{Ft}\right) / \mathrm{Fm}^{\prime}$. ETR was calculated as $\mathrm{ETR}=\Phi_{\mathrm{PSII}} \times \mathrm{PAR} \times 0.42$, where $\mathrm{PAR}$ is the quantum flux density of the photosynthetically active radiation and 0.42 is the average fraction of incident PAR absorbed by PSII.

\section{RESULTS}

For the first group with non-ventilated thalli (for a definition see the legend to table 1), data are presented for carbon isotope discrimination $(\Delta)$, net $\mathrm{CO}_{2}$ assimilation $(A)$ and ETR during a drying cycle for Pellia endiviifolia, P. epiphylla and Megaceros fuegiensis (figure 1). $P$. endiviifolia is normally found in more consistently wetted habitats even tolerating immersion, while $P$ epiphylla is comparatively more desiccationtolerant. Overall, the patterns of photosynthesis support our representation around an optimal TWC, with diffusional limitations occurring at higher water contents due to the surface liquid layer (above optimal TWC) affecting $\Delta, A$ and ETR. Within each species, the responses were modified; thus, for the desiccation intolerant $P$. endiviifolia, the transition from saturated (mean value, $120 \%$ ) to optimal operating TWC (mean value, $94 \%$ ) led to a sharp increase in the mean $\Delta$ values from 8.3 to $12.4 \%$, while mean $A$ also increased from 1.90 to $2.28 \mu \mathrm{mol} \mathrm{CO}_{2} \mathrm{~m}^{-2} \mathrm{~s}^{-1}$ (figure $1 a, b$ ). ETR tended to show a similar response, although the proportional limitation at high water content was lower (mean values $30-32 \mu \mathrm{mol} \mathrm{eq} \mathrm{m}^{-2} \mathrm{~s}^{-1}$; figure $1 c$ ). $A$ showed a surprisingly broad operating range across mean TWC (with a maximum at $82-94 \%$ ) as compared with narrower optimal TWC for $\Delta(94 \%)$ and ETR showed a wider optimal operating range at higher water contents (mean values, 94-120\% TWC).

The more desiccation-tolerant $P$. epiphylla (figure $1 d-f$ ) showed optimal photosynthetic characteristics across a wider operating range of mean TWC values (88-142\%), although the capacities for each parameter ( $\Delta, A$ and ETR) were generally lower than those for $P$. endiviifolia (figure $1 a-c$ ). The hornwort $M$. fuegiensis showed a much narrower operating range of maximal capacities for $\Delta, A$ and ETR (figure $1 g-i$ ) than the equivalent liverwort life forms at a mean TWC of $100 \%$. For the hornwort, the maximum $\Delta$ value occurred at a lower TWC than maximum assimilation or internal conductance (figure $1 g, h$; table 2 ). The external liquid-phase conductance when fully wetted was generally lower for the hornwort than the two liverworts, although $g_{\text {int }}$ were similar for all three life forms (table 2). 

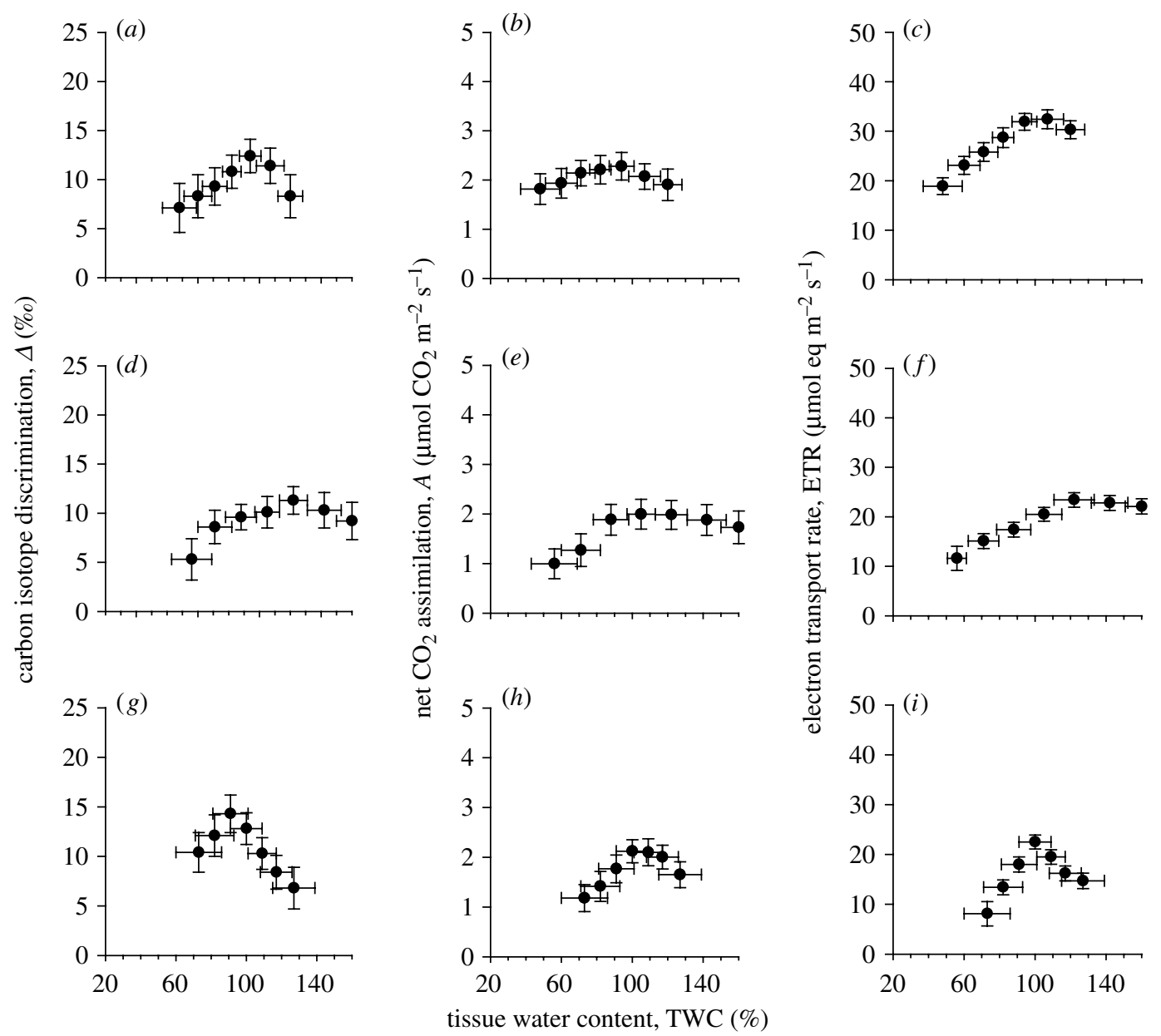

Figure 1. Carbon isotope discrimination ( 4 ), net $\mathrm{CO}_{2}$ assimilation $(A)$ and ETR during a drying cycle for Pellia endivifolia (a-c), P. epiphylla $(d-f)$ and $M$. fuegiensis $(g-i)$. Each value is the mean of five independent determinations during a drying curve, with the optimal TWC first being determined by blotting surface water and set to $100 \%$ before rewetting tissue to derive, progressively, surface liquid-phase limitation, optimal thallus operating capacity and subsequent biochemical limitation.

Table 2. Diffusion limitations, operating efficiencies and water use characteristics for contrasting bryophyte groups, and allied algal lineages. (Internal conductance $\left(g_{\text {int }}\right.$, column 1$)$ and operating efficiency (leakiness) of biophysical (2), and minimum surface liquid-phase conductance $\left(g_{\text {liq }}, 3\right)$, were derived from online discrimination data. Optimal WUE (4) was derived from fresh weight loss at maximal $\mathrm{CO}_{2}$ assimilation, converted to water loss on an area basis. Column 5 shows the mean tissue organic carbon isotope discrimination measured for three replicates.)

\begin{tabular}{|c|c|c|c|c|c|}
\hline & $g_{\text {int }}\left(\mu \mathrm{mol} \mathrm{m}{ }^{-2} \mathrm{~s}^{-1}\right)$ & CCM leakage (\%) & $g_{\text {liq }}\left(\mu \mathrm{mol} \mathrm{m}{ }^{-2} \mathrm{~s}^{-1}\right)$ & $\begin{array}{l}\text { WUE }\left(\mathrm{mol} \mathrm{CO}_{2} \mathrm{~mol}\right. \\
\left.\mathrm{H}_{2} \mathrm{O}^{-1} \cdot 10^{-3}\right)\end{array}$ & $\Delta_{\text {org }}(\%$ o $)$ \\
\hline P. endiviifolia & 10.8 & - & 23.6 & 0.66 & 21.8 \\
\hline P. epiphylla & 9.4 & - & 29.2 & 0.72 & 28.5 \\
\hline M. fuegiensis & 9.3 & - & 12.2 & 0.54 & 20.1 \\
\hline C. conicum & 39.1 & - & 31.9 & 1.56 & 24.1 \\
\hline L. cruciata & 38.0 & - & 40.2 & 1.51 & 23.3 \\
\hline M. polymorpha & 42.3 & - & 37.0 & 2.53 & 20.2 \\
\hline M. vincentianus & - & 30.4 & 30.9 & 0.53 & 13.3 \\
\hline P. carolinianus & - & 17.0 & 27.5 & 1.02 & 14.0 \\
\hline C. orbicularis & - & 31.6 & 18.6 & 0.28 & 11.3 \\
\hline C. reinhardtii & - & 5.5 & 28.2 & 0.79 & $\mathrm{n} / \mathrm{a}$ \\
\hline
\end{tabular}

In figure 2 , we present the photosynthetic characteristics of the second group (see the legend to table 1), liverworts with a range of habitat preferences and the degree of thallus ventilation (both in terms of cavities and intracellular airspaces). Conocephalum conicum and Lunularia cruciata show a similar broad operating range of $\Delta, A$ and ETR across mean TWCs ranging from 70 to $125 \%$ TWC, whereas
M. polymorpha has a much narrower optimal hydration (98\% TWC). ETR rates of $M$. polymorpha at well-watered TWC were generally much higher (maximum ETR of 45 versus 22 and 38 for C. conicum and L. cruciata, respectively), but declined rapidly at lower TWC values, indicating a higher susceptibility of the light harvesting apparatus to water deficits in this liverwort. 

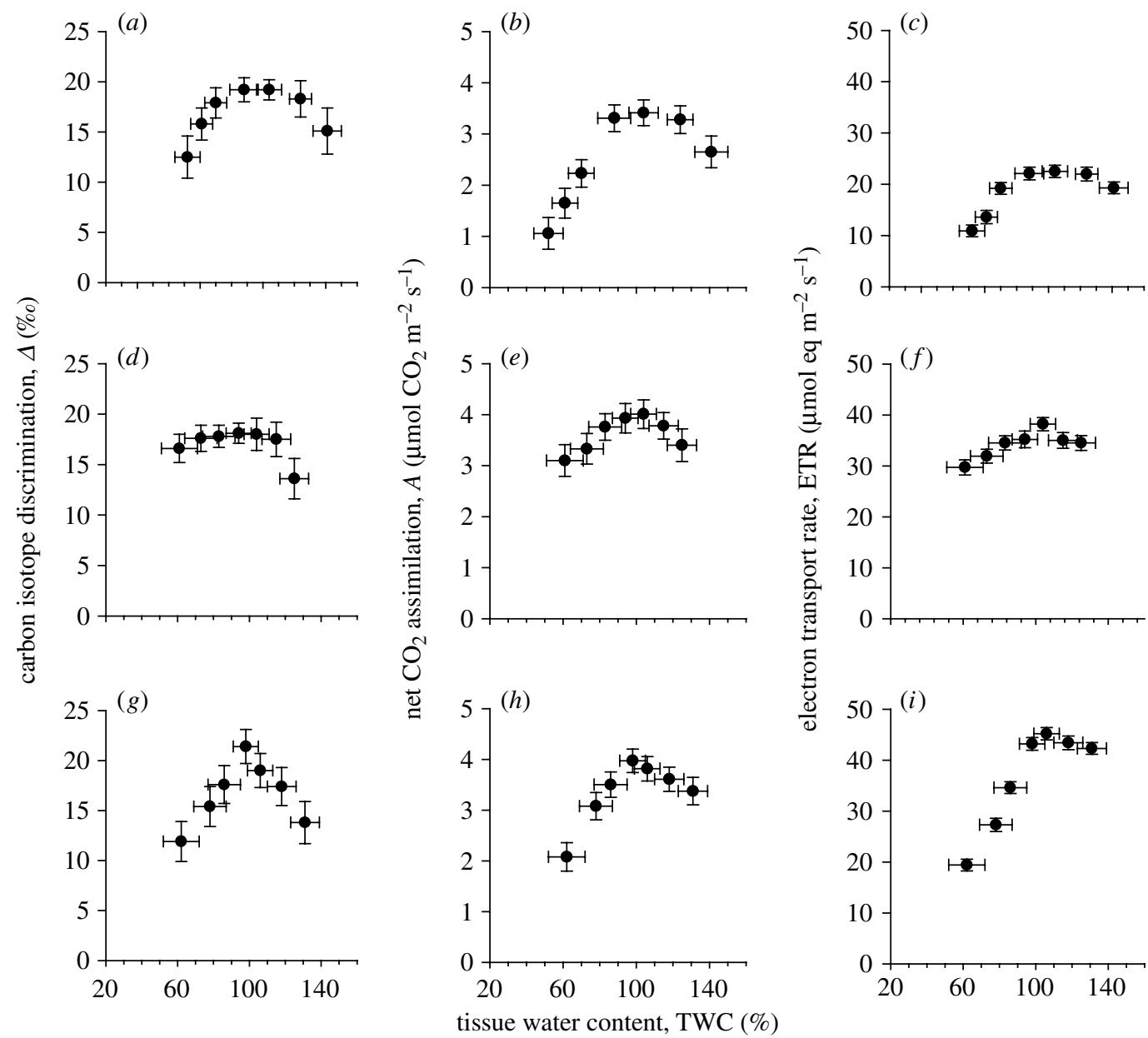

Figure 2. Carbon isotope discrimination $(\Delta)$, net $\mathrm{CO}_{2}$ assimilation $(A)$ and ETR during a drying cycle for $C$. conicum (a-c), L. cruciata $(d-f)$ and $M$. polymorpha $(g-i)$. Experimental details are the same as given in legend to figure 1 .

In figure 3 , we compare the assimilation characteristics of organisms with CCMs across the drying cycle, which also tended to show unimodal responses with maximal values at optimal TWCs. $\Delta$ was lower in Phaeoceros carolinianus than the other bryophytes (figure $3 a$ ), with a maximum of $6.1 \%$ at $89 \%$ TWC; while $A$ rates showed a range similar to the bryophytes with well-ventilated thalli (figure $3 b$ ), ETR was much

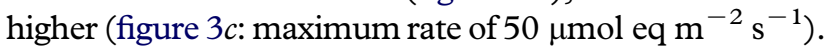
$\Delta$ was highest in $C$. orbicularis (figure $3 d$ ) and lowest in C. reinhardtii (figure $3 g$ ), although $A$ and ETR were low in both algae (albeit measured as a cell layer on a filter paper insert in the leaf cuvette). Considering the relatively constant $A$ and ETR across the drying curve for C. orbicularis (figure $3 e, f$ ) there was a wide range of $\Delta$ values expressed, which were sensitive to both liquidphase diffusion limitation and suboptimal water contents (figure $3 d$ ).

In order to summarize the key physiological parameters for each of these contrasting life forms, we plotted the isotope discrimination and optimal assimilation characteristics (figure 4) and tabulated the key derived parameters (internal conductance/CCM leakiness, external liquid-phase diffusion limitation and WUE) with organic carbon isotopic composition (table 2). The higher assimilation rates and isotope discrimination are clearly associated with the ventilated liverworts, as compared with the non-ventilated liverworts and hornworts (figure 4). For those organisms with a CCM (with additional data included for the pyrenoid-containing tissue from Megaceros vincentia$n u s)$, assimilation rates were more variable. The optimal assimilation rate for the hornwort $P$ carolinianus was equivalent to the ventilated liverworts, consistent with the observations made by Griffiths et al. (2004), but lower than the non-pyrenoidal $M$. fuegiensis (figure 4).

When tissue was fully wetted, a surficial layer of water provided an additional diffusional limitation to $\mathrm{CO}_{2}$ uptake, with lower values of online $\Delta$ found for all species included in our study (figures 1-3). In organisms without a CCM, the internal conductance is found at the optimal TWC (using maximal $\Delta_{\mathrm{opt}}$ values for each organism from figure 4). The drawdown of external $\mathrm{CO}_{2}$ mole fraction (when ambient $\mathrm{CO}_{2}, C_{\mathrm{a}}$ equals that at the tissue surface, $C_{\mathrm{s}}$ ) to that at the carboxylation site $\left(C_{\mathrm{c}}\right)$ then represents only the mesophyll or internal conductance $\left(g_{\text {int }}\right.$; table 2$)$. For fully wetted tissues, the lower $\Delta_{\text {wet }}$ reflects the additional drawdown of $\mathrm{CO}_{2}$ concentration from ambient air, through the surficial liquid layer, through mesophyll tissue, to the sites of carboxylation. Thus, the online discrimination measurements could be used to calculate the minimal liquid-phase conductance when wetted, from the difference between fully wetted $\left(\Delta_{\mathrm{wet}}\right)$ and optimal TWC $\left(\Delta_{\mathrm{opt}}\right)$ discrimination characteristics (table 2 , for details, see $\$ 2$ ). For 

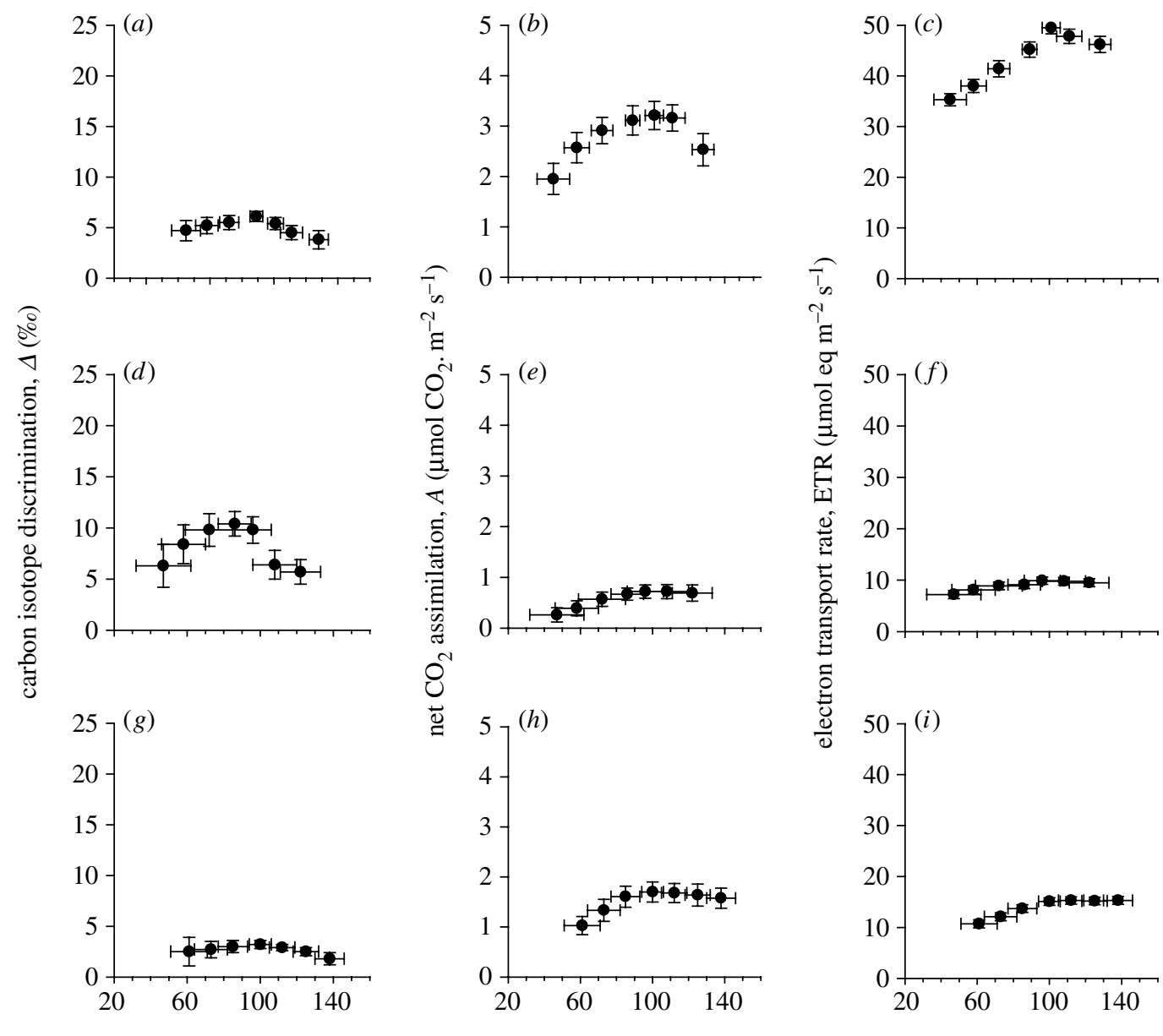

tissue water content, TWC $(\%)$

Figure 3. Carbon isotope discrimination $(\Delta)$, net $\mathrm{CO}_{2}$ assimilation $(A)$ and ETR during a drying cycle for $P$. carolinianus $(a-c)$, C. orbicularis $(d-f)$ and $C$. reinhardtii $(g-i)$. Experimental details are the same as given in legend to figure 1 .

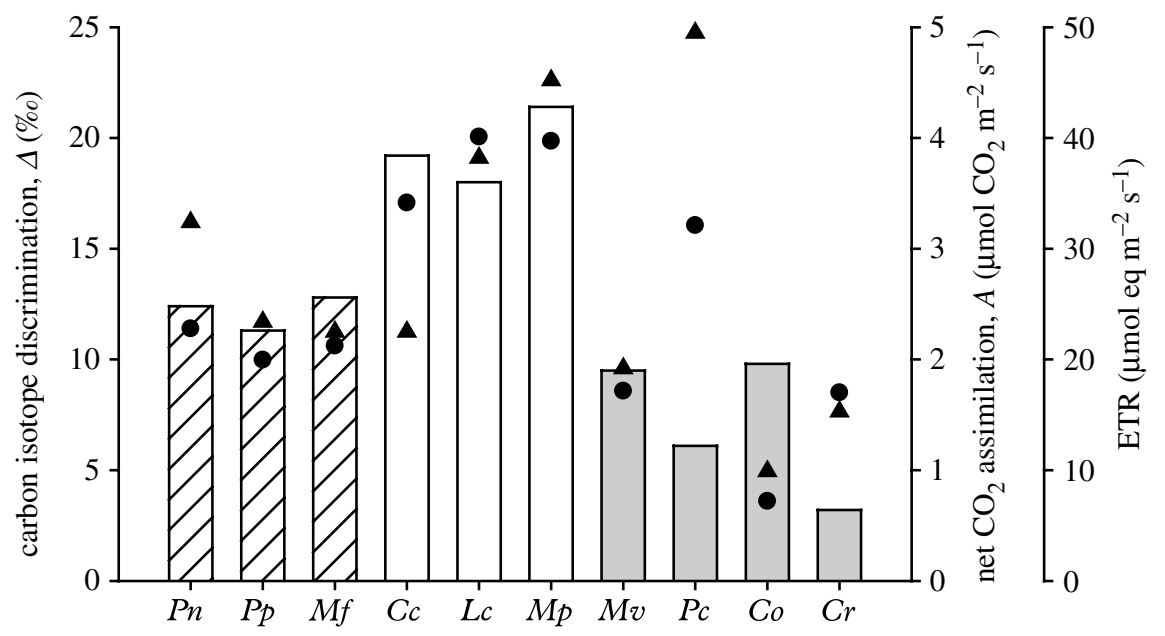

Figure 4. Comparative summary of carbon isotope discrimination ( $\Delta$, bar chart), net $\mathrm{CO}_{2}$ assimilation (filled circles) and ETR (filled triangles) at optimal TWC for contrasting bryophyte life forms. Data summarized from figures 1-3, collated to show nonventilated liverwort and hornwort thalli (hatched bars, Pn, Pellia endiviifolia; Pp, Pellia epiphylla; Mf, Megaceros fuegiensis), ventilated liverworts (blank bars, Cc, Conocephalum conicum; Lc, Lunularia cruciata; Mp, Marchantia polymorpha), and hornworts and algae with a CCM (grey bars, Mv, Megaceros vincentianus; Pc, Phaeoceros carolinianus; Co, Coleochaete orbicularis; Cr, Chlamydomonas reinhardtii).

organisms with pyrenoids, $\Delta_{\text {opt }}$ was used to calculate the extent of leakage from the CCM in hornworts and algae (table 2).

Firstly, $g_{\text {int }}$ was much lower for non-ventilated bryophyte thalli than for more complex, ventilated tissues $\left(9.3-10.8 \mu \mathrm{mol} \mathrm{m}^{-2} \mathrm{~s}^{-1}\right.$ for simple thalli, as compared with $38.0-42.3 \mu \mathrm{mol} \mathrm{m} \mathrm{m}^{-2} \mathrm{~s}^{-1}$ for ventilated thalli; table 2). Secondly, the mean $g_{\text {liq }}$ for simple, non-ventilated thalli (hornworts and liverworts: $24.7 \mu \mathrm{mol} \mathrm{m}^{-2} \mathrm{~s}^{-1}$ ) was lower than that for ventilated liverwort thalli $\left(36.4 \mathrm{mmol} \mathrm{m}^{-2} \mathrm{~s}^{-1}\right)$, suggesting that, when wetted with a layer of external water, the former are more limited by diffusion than the latter. As one would predict from the lower online $\Delta_{\text {opt }}$ values for 
certain of the tissues with a CCM (namely $P$. carolinianus and $C$. reinhardtii), leakage was lowest, or the efficiency of the CCM highest for these organisms (table 2). However, there was a difference in the efficiency of the two hornwort CCMs, with $P$. carolinianus nearly twice as efficient as pyrenoid-containing multiplastidic tissues from $M$. vincentianus (leakage 17 versus $30 \%$, respectively, table 2).

WUE, calculated as an integral of instantaneous $\mathrm{CO}_{2}$ assimilation and water loss rates per unit thallus area, also showed interesting characteristics according to bryophyte functional group (table 2). Overall, the simple, non-ventilated thalli (liverworts and hornworts) had a lower mean WUE than the more complex, ventilated liverwort thalli $(0.69$, as opposed to 1.87 , $\left.\mathrm{molCO}_{2} \cdot \mathrm{mol} \mathrm{H}_{2} \mathrm{O}^{-1} \cdot 10^{-3}\right)$. Finally, the organic carbon isotope ratio composition was calculated as $\Delta_{\text {org }}$, assuming a source $\mathrm{CO}_{2}$ composition of $-8 \%$, and while there were no statistical differences between the ventilated and non-ventilated thalli, a consistent pattern of low $\Delta$ was associated with the operation of a CCM in both hornworts and $C$. orbicularis (table 2).

\section{DISCUSSION}

\section{(a) Co-limitation of $\mathrm{CO}_{2}$ uptake and water loss for bryophyte life forms}

The lower overall conductances ( $g_{\text {liq }}$, liquid phase and, even more so $g_{\text {int }}$, mesophyll) for the non-ventilated thalli were consistent with gas exchange characteristics showing diffusion limitation (Slavík 1965; Proctor 1980; Green \& Lange 1994; Williams \& Flanagan 1996; Rice et al. 2001; Griffiths et al. 2004; Fletcher et al. 2005). By contrast, resistance to $\mathrm{CO}_{2}$ uptake was significantly lower for the ventilated thalli, suggesting that surface morphological features, as well as internal airspaces, and possibly biochemical differences, all help to maximize $\mathrm{CO}_{2}$ assimilation and support the notion of an evolutionary progression from simple to complex thalli. The possession of a CCM was generally associated with a higher external conductance in hornworts (perhaps reflecting the overall CCM capacity to increase the diffusion gradient into the non-ventilated thalli). However, the effectiveness of the CCM, in terms of the lowest degree of leakage, was most pronounced in $C$. reinhardtii, followed by $P$. carolinianus, with the latter requiring the highest ETR in support of CCM. These data are again consistent with the role of the CCM in non-ventilated hornworts as providing equivalence, in terms of carbon gain, to that of ventilated thalli (Hanson et al. 2002; Griffiths et al. 2004). However, the CCM rates would be a disadvantage in terms of the energetic demand in a low light environment, again leading to the conclusion that there was possibly little long-term physiological advantage in retaining a CCM for the early evolution of land plants in a high $\mathrm{CO}_{2}$ world in shaded habitats (Griffiths et al. 2004; Raven et al. 2008).

In terms of the integrated measures of performance, we note that instantaneous WUE distinguished simple, non-ventilated thalli, and their more advanced counterparts, with both higher diffusion limitation and lower WUE associated with the undifferentiated thalli. Additionally, the highest overall WUE found for
M. polymorpha was also consistent with such a narrow range of TWC to support maximal assimilation and ETR (figure 2; see discussion below; Proctor \& Tuba 2002).

Organic carbon isotope discrimination values were a good indicator of CCM occurrence, but not thallus or liquid-phase diffusion limitation, perhaps due to the variable proportion of respiratory $\mathrm{CO}_{2}$ derived from the substrate under natural growth conditions, which was not measured in this study. This would affect both the source signal (leading to higher apparent discrimination when source $\mathrm{CO}_{2}$ assumed to be $-8 \%$ ) with higher ambient concentrations providing a bonus for the improved diffusive supply (DeLucia et al. 2003). Finally, the general decrease in carbon isotope discrimination at low TWCs for all bryophytes is consistent with 'biochemical limitation' sensu Rice \& Giles (1996; Rice 2000; Hamerlynck et al. 2002), which could result from a declining rubisco activity and ETR. Alternatively, the low $\Delta$ could result from reduced $\mathrm{CO}_{2}$ supply, perhaps due to a loss of turgor, or declining aquaporin activity (Flexas et al. 2007a,b) in the desiccating thalli.

\section{(b) Isotope discrimination and bryophyte habitat preference then and now}

Some species showed an extremely narrow range of optimal water contents when isotope discrimination and electron transport were maximal ( $P$. endiviifolia, M. fuegiensis, M. polymorpha). By contrast, P. epiphylla, and the 'ventilated' thalli of Conocephalum and Lunularia, were more tolerant to desiccation, in that the photosynthetic characteristics $(A, \Delta, \mathrm{ETR})$ were maintained across a much wider range of TWC values. These responses are consistent with the observed habitat preferences for the two Pellia species (J. Duckett 2007, personal communication), while for Marchantia, the high WUE may mitigate such a limitation to distribution. This perhaps reduces the rate of water loss per unit carbon fixed to maximize the period of carbon gain, as compared with those other ventilated liverworts (C. conicum, L. cruciata), adapted to more xeric habitats.

Overall, the systematic losses in the operating efficiency of carbon gain (limited by low $g_{\text {int }}$ and $g_{\text {liq }}$, as internal and external conductances) and evaporative rate in simple, thalloid bryophytes can be partially offset by the operation of a CCM. The energetic demand of the carbon pump may limit activity at low light and lead to high rates of leakage, or alternatively require an inherently high ETR to drive the CCM in hornworts or C. orbicularis. However, for the first time, we have quantified both the physiological operations of a CCM in Coleochaete and show that they operate closer to the operating efficiencies of hornworts rather than in Chlamydomonas. Ultimately, however, our limited study suggests that the evolutionary progression of increased ventilation in liverwort life forms, associated with improved WUE, seems to have made a CCM redundant in all terrestrial plant lineages (with the except of most hornworts) under what was then a high $\mathrm{CO}_{2}$ world.

Meanwhile, the isotopic signals in bryophytes (Rundel et al. 1979; Teeri 1981; Proctor et al. 1992) 
and fossilized tissues (Fletcher et al. 2004, 2005; Loader et al. 2007) seem to reflect $\mathrm{CO}_{2}$ concentrations for growth in a palaeohistorical context. It seems likely that the emergence of a land-based biota increasingly reliant on stomata to control gaseous fluxes of water and $\mathrm{CO}_{2}$ (Edwards et al. 1998; Woodward 1998; Raven 2002) would have overshadowed the thalloid bryophytes in leaving a marker of their discrimination processes on the atmospheric $\mathrm{CO}_{2}$ signal. Meanwhile, the increasing development of soil organic carbon reserves would have led to the efflux of $\mathrm{CO}_{2}$ from soils tending to provide a respiratory bonus to the thalloid bryophytes appressed to their substrate, and shifted to a (probably) more ${ }^{13} \mathrm{C}$-depleted source $\mathrm{CO}_{2}$ to which they would have been predominantly exposed (see discussion above). At any event, these factors complicate the simple interpretation of bryophyte organic residues as markers of atmospheric $\mathrm{CO}_{2}$ concentration (Fletcher et al. 2006).

\section{(c) Bryophyte diversity in form and function: possibilities and practicalities for land plant evolution}

The hornworts represent an enigmatic group for which the phylogenetic relationship to other bryophytes, and the land plant progression, is still a matter of debate, primarily between proponents of a hornwort-basal versus liverwort-basal hypotheses (Qiu et al. 2006, 2007; Renzaglia et al. 2007). The diffusive limitations (external, when wetted, and internal, when likely to desiccate) of equivalent simple thalloid life forms (table 2), is consistent with a basal stature for such morphologies, particularly as a single chloroplast per cell in hornworts is also liable to decrease $g_{\text {int }}$. However, bryophytes with highly developed internal airspaces and pores leading to chambers, containing chlorenchyma protected from direct evaporative demands, are at least as efficient (in terms of carbon gain) as a simple thallus with a CCM, while their water use (as WUE) is considerably higher. As regards the land plant progression, despite hornwort sporophytes developing stomata (which may function analogously to those in moss sporophytes to aid the desiccation and spore dispersal: Renzaglia et al. 2007), there have been no other land plants to develop such a CCM prior to C4 or CAM pathways.

The origins and mechanistic functioning of the chloroplast pyrenoid, an organelle long associated with the algal CCM (and analogous to the cyanobacterial carboxysome, Badger et al. (1998)), is therefore found only in selected hornworts, of all land plant species. Without a more detailed genetic, molecular and physiological comparison of Coleochaete and hornwort pyrenoids, we can only speculate as to their origins and derivation (perhaps both from the Mesostigma lineage or from an even earlier common ancestor? Raven 2003; Burey et al. 2005). However, from a functional perspective, it is evident that the efficiency of the hornwort pyrenoid spans that of green algae (Chlamydomonas) and Charophyceae (Coleochaete), as seen in the data presented in figure 4 and table 2 . While we lack a detailed study of pyrenoidality or other CCM proxy (carbon isotope composition) for hornworts (Smith \& Griffiths 1996a,b; Griffiths et al. 2004), a most recent phylogenetic re-evaluation (Duff et al. 2007) is still consistent with the contention that pyrenoid and uniplastidicity are ancestral characters. The loss of a CCM in more advanced, multiplastidic thalli seems compelling, although the possibility of the pyrenoid being lost and regained (sensu Nozaki et al. (2002) for Chlamydomonas and Chloromonas) may also hold for some of the hornwort groups (J. Duckett 2007, personal communication; Duff et al. 2007).

Physiologically, it is from here a short step to the form, function and molecular basis to our understanding (or rather the lack of it!) for the pyrenoid in Chlamydomonas and other algal lineages. While there are undoubtedly some CCM systems which function in the absence of a pyrenoid (Raven 1997a,b; Raven et al. 2008), we contend that the majority of the significant aquatic global carbon fixation mediated by noncyanobacterial microbes (Raven et al. 2008) is mediated by a pyrenoid-based CCM. To date, there are no candidate genes, proteins or specific structures which are thought to comprise a pyrenoid, other than the associated starch sheath (Izumo et al. 2007), and internal pyrenoid complement of rubisco (Lacoste-Royal \& Gibbs 1987; Vaughn et al. 1990; Borkhsenious et al. 1998), rubisco activase (McKay et al. 1991), nitrate reductase (Okabe \& Okada 1990), Calvin cycle enzymes, photosystem I and lumenal carbonic anhydrase-enriched trans-thylakoid lamellae (Villarejo et al. 1998; Moroney \& Ynalvez 2007). While we are currently undertaking work on a pyrenoid proteome and also investigating the relationship between rubisco structure and function in the chloroplast pyrenoid, our closest guess to the normal pyrenoid structure is some type of aggregation mechanism associated with rubisco, which may be related either to rubisco holoenzyme amino acid residue interactions or some additional plastoskeleton structures. There is evidence for the existence of complex filamentous networks in bacteria (CarballidoLópez \& Errington 2003), which could have a counterpart in the endosymbiotically inherited plastids or during cell division. At any event, solving the riddle of the pyrenoid structure and operation for installation in C3 plants may provide a more tractable alternative to the introduction of $\mathrm{C} 4$ biochemistry into certain crop species.

Finally, it has been postulated that hornworts may have diversified in the lee of the angiosperms (M. Chase 2002, personal communication) in a manner similar to that postulated for the pteridophytes (Schneider et al. 2004). More recently, the diversification of liverworts (Ahonen et al. 2003) and specifically leafy liverworts, has been considered (Heinrichs et al. 2007), but a group with earlier origins would provide more compelling evidence. Ultimately, it seems that the bryophytes should not be considered as evolutionary relicts, when such highly productive and diverse life forms dominate carbon sequestration over such a large area of the globe (Clymo \& Hayward 1982; Campbell et al. 2000; Gunnarsson 2005).

We may therefore not necessarily invoke the alternation of generations, and limitations of the haploid vegetative phase for growth, in having constrained bryophyte diversification, or the global 
productivity. However, the fossil record suggests a slow rate of bryophyte evolution and hence the extent of sexual recombination in bryophytes is low and the mutations in the haploid state are more likely to be lethal. Ultimately, bryophytes seem to represent a contradiction in terms: dismissed in textbooks as being 'primitive', their physiological progression (development of a land-based CCM, origins of stomata and adoption of internal mesophyll ventilation), together with their observed global diversity and productivity, belies such a definition. The interplay between diffusive or carboxylation limitations revealed in this paper support the anatomical and molecular progression. Further investigations into the molecular correlates of bryophyte physiology and diversification may hold additional insights for a number of key processes determining the evolution and success of higher plants, both in the past and for the future.

We thank D. C. Cargill and J. C. Villarreal for the hornwort material. This research was supported by grant BFR06/30 from the Luxemburg Ministry of Culture, Higher Education and Research, and by the Ecology Section of the National Museum of Natural History, Luxemburg (Dr Christian Ries), as well as by the Department of Plant Sciences.

\section{REFERENCES}

Ahonen, I., Muona, J. \& Piipo, S. 2003 The relationships between the subfamilies of the liverwort family Lejeuneaceae (Hepaticae). Bryologist 106, 297-308. (doi:10.1639/ 0007-2745(2003)106[0297:ITPOTL]2.0.CO;2)

Apostolakos, P., Galatis, B. \& Mitrakos, K. 1982 Studies on the development of the air pores and air chambers of Marchantia palacea: 1. Light microscopy. Ann. Bot. 49, 377-396.

Badger, M. R., Andrews, T. J., Whitney, S. M., Ludwig, M., Yellowlees, D. C., Leggat, W. \& Price, G. D. 1998 The diversity and co-evolution of Rubisco, plastids, pyrenoids and chloroplast-based CCMs in the algae. Can. F. Bot. Rev. Can. Bot. 76, 1052-1071. (doi:10.1139/cjb76-6-1052)

Berry, J. A. 1989 Studies of mechanisms affecting the fractionation of carbon isotopes in photosynthesis. In Ecological studies, vol. 68 (eds P. W. Rundel, J. R. Ehleringer \& K. A. Nagy). Stable isotopes in ecological research, pp. 82-94. New York, NY: Springer.

Borkhsenious, O. N., Mason, C. B. \& Moroney, J. V. 1998 The intracellular localization of ribulose-1,5-bisphosphate carboxylase/oxygenase in Chlamydomonas rienhardtii. Plant Physiol. 116, 1585-1591. (doi:10.1104/pp.116.4.1585)

Burey, S. C., Fathi-Nejad, S., Poroyko, V., Steiner, J. M., Löffelhardt, W. \& Bohnert, H. J. 2005 The central body of the cyanelles of Cyanophora paradoxa: a eukaryotic carboxysome? Can. F. Bot. Rev. Can. Bot. 83, 758-764. (doi:10.1139/b05-060)

Campbell, C., Vitt, D. H., Halsey, L. A., Campbell, I. D., Thornmann, M. N. \& Bayley, S. E. 2000 Net primary production and standing biomass in northern continental weltands, NOR-X-369. Edmonton, Alberta: Nature Resources Canada, Canadian Forest Service, Northern Forestry Centre, pp. 1-57.

Carballido-López, R. \& Errington, J. 2003 A dynamic bacterial cytoskeleton. Trends Cell Biol. 13, 577-583. (doi:10.1016/j.tcb.2003.09.005)

Clymo, R. S. \& Hayward, P. M. 1982 The ecology of Sphagnum. In Bryophyte ecology (ed. A. J. E. Smith), pp. 229-289. London, UK; New York, NY: Chapman and Hall Ltd.
DeLucia, E. H., Turnbull, M. H., Walcroft, A. S., Griffin, K. L., Tissue, D. T., Glenny, D., McSeveny, T. M. \& Whitehead, D. 2003 The contribution of bryophytes to the carbon exchange for a temperate rainforest. Glob. Change Biol. 9, 1158-1170. (doi:10.1046/j.1365-2486.2003. 00650.x)

Duff, R. J., Villarreal, J. C., Cargill, D. C. \& Renzaglia, K. S. 2007 Progress and challenges toward developing a phylogeny and classification of the hornworts. Bryologist 110, 241-243. (doi:10.1639/0007-2745(2007)110[214: PACTDA]2.0.CO;2)

Edwards, D., Wellman, C. H. \& Axe, L. 1998 Interrelationships between primitive embryophytes and the fossil record of early land plants: too little and too late? In Bryology for the twenty-first century (eds J. W. Bates, N. W. Ashton \& J. G. Duckett), pp. 15-43. Leeds, UK: British Bryological Society.

Evans, J. R., Sharkey, T. D., Berry, J. A. \& Farquhar, G. D. 1986 Carbon isotope discrimination measured concurrently with gas exchange to investigate $\mathrm{CO}_{2}$ diffusion in leaves of higher plants. Aust. F. Plant Physiol. 13, 281-292.

Farquhar, G. D., Ehleringer, J. R. \& Hubick, K. T. 1989 Carbon isotope discrimination and photosynthesis. Annu. Rev. Plant Physiol. Plant Mol. Biol. 40, 503-537. (doi:10. 1146/annurev.pp.40.060189.002443)

Fletcher, B. J., Beerling, D. J. \& Chaloner, W. G. 2004 Stable carbon isotopes and the metabolism of the terrestrial Devonian organism Spongiophyton. Geobiology 2, 107-119. (doi:10.1111/j.1472-4677.2004.00026.x)

Fletcher, B. J., Beerling, D. J. \& Brentnall, S. J. 2005 Fossil bryophytes as recorders of ancient $\mathrm{CO}_{2}$ levels: experimental evidence and a Cretaceous case study. Glob. Biogeochem. Cycle 19, GB3012. (doi:10.1029/ 2005GB002495)

Fletcher, B. J., Brentnall, S. J., Quick, W. P. \& Beerling, D. J. 2006 BRYOCARB: a process-based model of thallose liverwort carbon isotope fractionation in response to $\mathrm{CO}_{2}$, $\mathrm{O}_{2}$, light and temperature. Geochim. Cosmochim. Acta 70, 5676-5691. (doi:10.1016/j.gca.2006.01.031)

Flexas, J., Ribas-Carbó, M., Diaz-Espejo, A., Galmés, J. \& Medrano, H. 2007a Mesophyll conductance to $\mathrm{CO}_{2}$ current knowledge and future prospects. Plant Cell Environ. 31, 602-621. (doi:10.1111/j.1365-3040.2007. 01757.x)

Flexas, J., Diaz-Espejo, A., Galmés, J., Kaldenhoff, R., Medrano, H. \& Ribas-Carbo, M. 2007b Rapid variations of mesophyll conductance in response to changes in $\mathrm{CO}_{2}$ concentration around leaves. Plant Cell Environ. 30, 1284-1298. (doi:10.1111/j.1365-3040.2007.01700.x)

Graham, L. E. \& Gray, J. 2001 The origin, morphology, and ecophysiology of early embryophytes: neontological and paleontological perspectives. In Plants invade the land, evolutionary and environmental perspectives (eds P. G. Gensel \& D. Edwards), pp. 140-158. New York, NY: Columbia University Press.

Graham, L. E., Wilcox, L. W., Cook, M. E. \& Gensel, P. G. 2004 Resistant tissues of modern marchantioid liverworts resemble enigmatic early Paleozoic microfossils. Proc. Natl Acad. Sci. USA 101, 11 025-11 029. (doi:10.1073/pnas. 0400484101)

Green, T. G. A. \& Lange, O. L. 1994 Photosynthesis in poikilohydric plants: a comparison of lichens and bryophytes. In Ecophysiology of photosynthesis, vol. 100 (eds E.-D. Schulze \& M. M. Caldwell). Ecological studies, pp. 319-341. Berlin, Germany: Springer.

Griffiths, H., Maxwell, K., Richardson, D. \& Robe, W. 2004 Turning the land green: inferring photosynthetic physiology and diffusive limitations in early bryophytes. 
In The evolution of plant physiology: from whole plants to ecosystems (eds A. R. Hemsley \& I. Poole), pp. 3-16. Amsterdam, The Netherlands: Elsevier Academic Press.

Gunnarsson, U. 2005 Global patterns of Sphagnum productivity. F. Bryol. 27, 269-279. (doi:10.1179/174328 205X70029)

Hamerlynck, E. P., Csintalan, Z., Nagy, Z., Tuba, Z., Goodin, D. \& Henebry, G. M. 2002 Ecophysiological consequences of contrasting microenvironments on the desiccation tolerant moss Tortula ruralis. Oecologia 131, 498-505. (doi:10.1007/s00442-002-0925-5)

Hanson, D., Andrews, T. J. \& Badger, M. R. 2002 Variability of the pyrenoid-based $\mathrm{CO}_{2}$ concentrating mechanism in hornworts (Anthocerotophyta). Funct. Plant Biol. 29, 407-416. (doi:10.1071/PP01210)

Heinrichs, J., Hentschel, J., Wilson, R., Feldberg, K. \& Schneider, H. 2007 Evolution of leafy liverworts (Jungermanniidae, Marchantiophyta): estimating divergence times from chloroplast DNA sequences using penalized likelihood with integrated fossil evidence. Taxon 56, 31-44.

Ingrouille, M. J. \& Eddie, B. 2006 Plants: diversity and evolution. Cambridge, UK: Cambridge University Press.

Izumo, A., Fujiwara, S., Oyama, Y., Satoh, A., Fujita, N., Nakamura, Y. \& Tsuzuki, M. 2007 Physicochemical properties of starch in Chlorella change depending on the $\mathrm{CO}_{2}$ concentration during growth: comparison of structure and properties of pyrenoid and stroma starch. Plant Sci. 172, 1138-1147. (doi:10.1016/j.plantsci.2007. 03.001)

Lacoste-Royal, G. \& Gibbs, S. P. 1987 Immunocytochemical localization of ribulose-1,5-bisphosphate carboxylase in the pyrenoid and thylakoid region of the chloroplast of Chlamydomonas reinhardtii. Plant Physiol. 83, 602-606.

Lewis, L. A. \& McCourt, R. M. 2004 Green algae and the origin of land plants. Am. F. Bot. 91, 1535-1556. (doi:10. 3732/ajb.91.10.1535)

Loader, N. J., McCarroll, D., van der Knaap, W. O., Robertson, I. \& Gagen, M. 2007 Characterizing carbon isotopic variability in Sphagnum. Holocene 17, 403-410. (doi:10.1177/0959683607076474)

Marschall, M. \& Proctor, M. C. F. 2004 Are bryophytes shade plants? Photosynthetic light responses and proportions of chlorophyll $a$, chlorophyll $b$ and total carotenoids. Ann. Bot. 94, 593-603. (doi:10.1093/aob/ mch 178)

Maxwell, K. \& Johnson, G. N. 2000 Chlorophyll fluorescence: a practical guide. F. Exp. Bot. 51, 659-668. (doi:10.1093/jexbot/51.345.659)

McKay, R. M. L., Gibbs, S. P. \& Vaughn, K. C. 1991 RubisCo activase is present in the pyrenoid of green algae. Protoplasma 162, 38-45. (doi:10.1007/BF01403899)

Moroney, J. V. \& Ynalvez, R. A. 2007 Proposed carbon dioxide concentrating mechanism in Chlamydomonas reinhardtii. Eukaryot. Cell 6, 1251-1259. (doi:10.1128/ EC.00064-07)

Nozaki, H., Onishi, K. \& Morita, E. 2002 Differences in pyrenoid morphology are correlated with differences in the $\mathrm{rbcL}$ genes of members of the Chloromonas lieneage (Volvocales, Chlorophyceae). F. Mol. Evol. 55, 414-430. (doi:10.1007/s00239-002-2338-9)

Okabe, Y. \& Okada, M. 1990 Nitrate reductase activity and nitrite in native pyrenoids purified from the green alga Bryopsis maxima. Plant Cell Physiol. 31, 429-432.

Proctor, M. C. F. 1980 Diffusion resistance in bryophytes. In Plants and their atmospheric environment (eds J. Grace, E. D. Ford \& P. G. Jarvis), pp. 219-229. Oxford, UK: Blackwell Scientific.

Proctor, M. C. F. \& Pence, V. C. 2002 Vegetative tissues: bryophytes, vascular resurrection plants and vegetative propagules. In Desiccation and survival in plants: drying out without dying (eds M. Black \& H. W. Pritchard), pp. 207-237. Wallingford, UK: CABI Publishing.

Proctor, M. C. F. \& Tuba, Z. 2002 Poikilohydry and homoihydry: antithesis or spectrum of possibilities. New Phytol. 156, 327-349. (doi:10.1046/j.1469-8137.2002. 00526.x)

Proctor, M. C. F., Raven, J. A. \& Rice, S. K. 1992 Stable carbon isotope discrimination measurements in Sphagnum and other bryophytes: physiological and ecological implications. F. Bryol. 17, 193-202.

Proctor, M. C. F., Nagy, Z., Csintalan, Z. \& Takacs, Z. 1998 Water-content components in bryophytes: analysis of pressure volume relationships. F. Exp. Bot. 49, 1845-1854. (doi:10.1093/jexbot/49.328.1845)

Proctor, M. C. F., Oliver, M. J., Wood, A. J., Alpert, P., Starck, L. R., Cleavitt, N. L. \& Mishler, B. D. 2007 Desiccation-tolerance in bryophytes: a review. Bryologist 110, 595-621. (doi:10.1639/0007-2745(2007)110[595: DIBAR]2.0.CO;2)

Qiu, Y. L. et al. 2006 The deepest divergences in land plants inferred from phylogenomic evidence. Proc. Natl Acad. Sci. USA 103, 15 511-15 516. (doi:10.1073/pnas. 0603335103)

Qiu, Y. L. et al. 2007 A nonflowering land plant phylogeny inferred from nucleotide sequences of seven chloroplast, mitochondrial, and nuclear genes. Int. F. Plant Sci. 168, 691-708. (doi:10.1086/513474)

Raven, J. A. $1997 a$ Inorganic carbon acquisition by marine autotrophs. Adv. Bot. Res. 27, 85-209.

Raven, J. A. $1997 b$ Putting the C in phycology. Eur. F. Phycol. 32, 319-333. (doi:10.1080/09670269710001737259)

Raven, J. A. 2002 Selection pressures on stomatal evolution. New Phytol. 153, 371-386. (doi:10.1046/j.0028-646X. 2001.00334.x)

Raven, J. A. 2003 Carboxysomes and peptidoglycan walls of cyanelles: possible physiological functions. Eur. F. Phycol. 38, 47-53. (doi:10.1080/0967026031000096245)

Raven, J., Cockell, C. \& De La Rocha, C. 2008 The evolution of inorganic carbon concentrating mechanisms in photosynthesis. Phil. Trans. R. Soc. B 363, 2641-2650. (doi:10. 1098/rstb.2008.0020)

Renzaglia, K. S., Duff, R. J., Nickrent, D. L. \& Garbary, D. J. 2004 Vegetative and reproductive innovations of early land plants: implications for a unified phylogeny. Phil. Trans. $R$. Soc. B 355, 769-793. (doi:10.1098/rstb.2000.0615)

Renzaglia, K. S., Schuette, S., Duff, R. J., Ligrone, R., Shaw, A. J., Mishler, B. D. \& Duckett, J. G. 2007 Bryophyte phylogeny: advancing the molecular and morphological frontiers. Bryologist 110, 179-213. (doi:10.1639/00072745(2007)110[179:BPATMA]2.0.CO;2)

Rice, S. K. 2000 Variation in carbon isotope discrimination within and among Sphagnum species in a temperate wetland. Oecologia 123, 1-8. (doi:10.1007/s004420050983)

Rice, S. K. \& Giles, L. 1996 The influence of water content and leaf anatomy on carbon isotope discrimination and photosynthesis in Sphagnum. Plant Cell Environ. 19, 118-124. (doi:10.1111/j.1365-3040.1996.tb00233.x)

Rice, S. K., Collins, D. \& Anderson, A. M. 2001 Functional significance of variation in bryophyte canopy structure. Am. F. Bot. 88, 1568-1576. (doi:10.2307/3558400)

Rundel, P. W., Stichler, W. \& Ziegler, H. 1979 Carbon and hydrogen isotope ratios of bryophytes from arid and humid regions. Oecologia 44, 91-94. (doi:10.1007/ BF00346404)

Schneider, H., Schuettpels, E., Pryer, K. M., Cranfill, R., Magallon, S. \& Lupia, R. 2004 Ferns diversified in the shadow of angiosperms. Nature 428, 553-557. (doi:10. 1038/nature02361) 
Schumaker, R. \& Váňa, J. 2005 Identification keys to the liverworts and hornworts of Europe and Macaronesia. Poznan, Poland: Sorus.

Seibt, U., Rajabi, A., Griffiths, H. \& Berry, J. A. 2008 Carbon isotopes and water use efficiency: sense and sensitivity. Oecologia 155, 441-454. (doi:10.1007/s00442-007-0932-7)

Shaw, J. \& Renzaglia, K. S. 2004 Phylogeny and diversification of bryophytes. Am. F. Bot. 91, 1557-1581. (doi:10. 3732/ajb.91.10.1557)

Slatyer, R. O. 1967 Plant water relationships. London, UK: Academic Press.

Slavik, B. 1965 The influence of decreasing hydration level on photosynthetic rate in the thalli of the hepatic Conocephalum conicum. In Water stress in plants (ed. B. Slavík), pp. 195-201. The Hague, The Netherlands: Dr W. Junk Publishers.

Smith, E. C. \& Griffiths, H. $1996 a$ The occurrence of the chloroplast pyrenoid is correlated with the activity of a $\mathrm{CO}_{2}$-concentrating mechanism and carbon isotope discrimination in lichens and bryophytes. Planta 198, 6-16. (doi:10.1007/BF00197580)

Smith, E. C. \& Griffiths, H. $1996 b$ A pyrenoid-based carbon concentrating mechanism is present in terrestrial bryophytes of the class Anthocerotae. Planta 200, 203-212.

Smith, E. C. \& Griffiths, H. 2000 The role of carbonic anhydrase in photosynthesis and the activity of the carbon concentrating mechanism in bryophytes of the class Anthocerotae. New Phytol. 145, 29-37. (doi:10.1046/ j.1469-8137.2000.00559.x)

Stoneburner, A. R., Wyatt, I. J. \& Odrzykoski, I. 1991 Applications of enzyme electrophoresis to bryophyte systematics and population biology. Adv. Bryol. 4, 1-27.

Surzycki, S. J. 1971 Synchronously grown cultures of Chlamydomonas reinhardii. Methods Enzymol. 23, 67-73.

Taylor, T. N. \& Haas, H. 2005 Life history biology of early land plants: deciphering the gametophyte phase. Proc. Natl
Acad. Sci. USA 102, 5892-5897. (doi:10.1073/pnas. 0501985102)

Teeri, J. A. 1981 Stable carbon isotope analysis of mosses and lichens growing in xeric and moist habitats. Bryologist 84, 82-84. (doi: 10.2307/3242982)

Turmel, M., Pombert, J.-F., Charlebois, P., Otis, C. \& Lemieux, C. 2007 The green algal ancestry of land plants as revealed by the chloroplast genome. Int. F. Plant Sci. 168, 679-689. (doi:10.1086/513470)

Vaughn, K. C., Campbell, E. O., Hasegawa, J., Owen, H. A. \& Renzaglia, K. S. 1990 The pyrenoid is the site of ribulose 1,5-bisphosphate carboxylase/oxygenase accumulation in the hornwort (Bryophyta: Anthocerotae) chloroplast. Protoplasma 156, 1117-1129. (doi:10.1007/ BF01560650)

Villarejo, A., Orus, I., Ramazanov, Z. \& Martinez, F. 1998 A 38-kilodalton low- $\mathrm{CO}_{2}$-inducible polypeptide is associated with the pyrenoid in Chlorella vulgaris. Planta 206, 416-425. (doi:10.1007/s004250050417)

Wellman, C. H., Osterloff, P. L. \& Mohiuddin, U. 2003 Fragments of the earliest land plant. Nature 425, 282-285. (doi:10.1038/nature01884)

Williams, T. G. \& Flanagan, L. B. 1996 Effect of changes in water content on photosynthesis, transpiration and discrimination against ${ }^{13} \mathrm{CO}_{2}$ and $\mathrm{C}^{18} \mathrm{O}^{16} \mathrm{O}$ in Pleurozium and Sphagnum. Oecologia 108, 38-46. (doi:10.1007/ BF00333212)

Wilson, R., Heinrichs, J., Hentschel, J., Gradstein, S. R. \& Schneider, H. 2007 Steady diversification of derived liverworts under Tertiary climatic fluctuations. Biol. Lett. 3, 566-569. (doi:10.1098/rsbl.2007.0287)

Wood, A. J. 2007 The nature and distribution of vegetative desiccation-tolerance in hornworts, liverworts and mosses. Bryologist 110, 163-177. (doi:10.1639/00072745(2007)110[163:IENFIB]2.0.CO;2)

Woodward, F. I. 1998 Do plants really need stomata? F. Exp. Bot. 49, 471-480. (doi:10.1093/jexbot/49.suppl_1.471) 